\title{
Human immunodeficiency virus as a sexually transmitted disease: Manitoba's HIV unlinked seroprevalence study
}

\author{
Laila Sekla, MBBCh, PhD, Gregory hammond, MD, Robert Tate, MSc, Walter Stackiw, BSc, \\ GUDRUN EIBISCH, RT, SHERLYN SHEWCHOOK BN, RN
}

\begin{abstract}
L Sekla, G Hammond, R Tate, W Stackiw, G Eibisch, S Shewchook. Human immunodeficiency virus as a sexually transmitted disease: Manitoba's HIV unlinked seroprevalence study. Can J Infect Dis 1992;3(6):295-298.
\end{abstract}

\begin{abstract}
OBJEctrve: To determine the prevalence of human immunodeficiency virus (HIV)-1 infections. Design: An unlinked seroprevalence study on all 'left over' blood submitted for syphilis testing during three consecutive six month periods (April 1, 1990 to September 30, 1991). After the capture of demographic data, sera to be tested for antibodies were stripped of all personal identifiers and assigned a random number. The study fulfilled Canadian ethical guidelines. Participants: Persons with a valid Manitoba Health Services Commission number were included only once in a study year. Persons were enrolled into one of five categories: infants, injection drug users, pregnant women, persons investigated for sexually transmitted diseases (STD) and routine testing. Results: Of the 50,929 persons tested, $133(0.26 \%)$ were positive, a low prevalence of HIV infections. A significant increase in positivity was noticed in the second study period. While $77.7 \%$ of those tested were women, only $10(0.025 \%)$ were positive for HIV. The rate of positivity for pregnant women was 0.72 per 10,000 tested. Of the 11,314 males tested, $123(1.08 \%)$ had antibodies. Most of the positives were males in the STD category residing in Winnipeg: for them. the rate of positivity increased by middle age, while the rate of testing decreased with each decade of age (from age 15 to 44 years). Drscussion/RecomMENDATION: This is the first report from a sentinel laboratory in Canada of an unlinked seroprevalence study in persons with STD. Results suggest an urgent need to target strategies for the control of HIV for persons with STD. particularly males in urban centres, by routine HIV testing for STD patients.
\end{abstract}

Key Words: Human immunodeficiency virus seroprevalence. Sexually transmitted disease

\section{Le virus de l'immunodéficience humaine, maladie transmise sexuellement: étude indépendante sur la séroprévalence du VIH au Manitoba}

OвJестrF: Déterminer la prévalence des infections au virus de l'immunodéficience humaine (VIH) - 1. MoDÈLE: Une étude de séroprévalence indépendante sur tout le sang en surplus soumis à une recherche de syphillis durant trois périodes consécutives de 6 mois ( $1^{\mathrm{er}}$ avril 1990 au 30 septembre 1991). Après la cueillette des données démographiques, les sérums à analyser à l'égard des anticorps ont été débarrassés de toute marque d'identification personnelle et on leur a assigné un numéro au hasard. L'étude répondait aux directives déontologiques canadiennes. Participants: Les personnes porteuses d'un numéro valide de la Manitoba 


\begin{abstract}
Health Services Commission ont été incluses une seule fois dans une études/année. Les personnes ont étẻ réparties dans l'une des 5 catégories suivantes: nourrissons, utilisateurs de drogues intraveineuses, femmes enceintes, personnes ayant subi des analyses de détection de maladies transmises sexuellement (MTS) et analyses de routine. RÉsultats: Des 50929 personnes testées, 133 (0.26 \%) étaient positives, soit une prévalence faible d'infection au VIH. Une augmentation significative de la positivité a été notée durant le deuxième période de l'étude. Alors que $77,7 \%$ des sujets testés étaient des femmes, seulement 10 $(0,025 \%)$ étaient positives à l'égard du VIH. Le taux de positivité chez les femmes enceintes était de 0,72 par 10000 testées. Des 11314 hommes testés, 123 (1,08\%) avaient des anticorps. La plupart des séropositifs étaient de sexe masculin dans la catégorie MTS qui résidaient à Winnipeg. Pour eux. le taux de positivité s'accroissait à l'âge adulte, alors que les taux d'analyses diminuaient avec chaque tranche de 10 ans (entre 15 et 44 ans). Discussion/Recommandations: Il s'agit du premier rapport d'un laboratoire sentinelle au Canada, sur une étude de séroprévalence indépendante chez les personnes atteintes de MTS. Les résultats donnent à penser qu'il faut établir d'urgence des stratégies de ciblage pour le contrôle du VIH chez les personnes atteintes de MTS, particulièrement chez les hommes des centres urbains, par l'analyse de routine du VIH chez les patients porteurs de MTS.
\end{abstract}

$\mathrm{T}$ HE PREVALENCE OF HUMAN IMMUNODEFICIENCY VIRUS (HIV)- 1 infection in Canada is unknown; yet this information is essential to target health resources. To obtain accurate data, the Royal Society of Canada (1) recommended anonymous unlinked seroprevalence studies, and the Federal Centre for Acquired Immune Deficiency Syndrome (AIDS) set up guidelines for such studies to meet legal, ethical and scientific requirements (2). The National Health Research and Development Program provided funds for proposals submitted from various laboratories across Canada. Results of the 18-month Manitoba unlinked HIV seroprevalence study are presented. This report, which focuses on persons tested for a sexually transmitted disease (STD), represents the first such report in Canada.

\section{METHODOLOGY}

The study design has been detailed previously (3). Briefly, all 'left over' blood submitted to the Cadham Provincial Laboratory for syphilis testing were reviewed

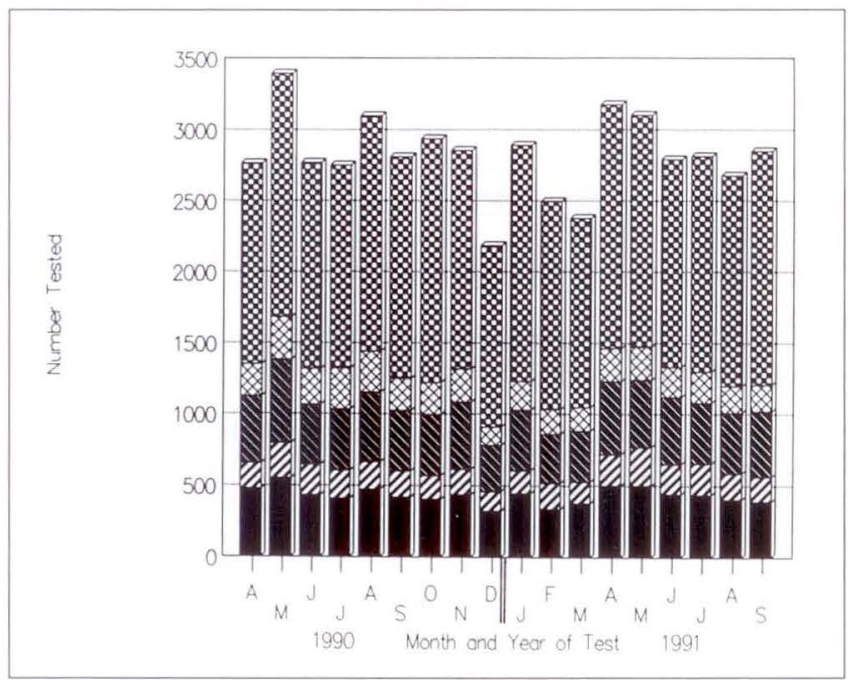

Figure 1) The number of males and females tested for each of the main enrollment categories for each of the 18 months of study. Male sexually transmitted diseases; Male routine: Female sexually transmitted diseases:

Female routine; Prenatal for inclusion in the HIV seroprevalence study (this laboratory is the sole provider of this diagnostic testing in Manitoba). Persons with a valid Manitoba Health Services Commission number were included only once during each study year. A mainframe computer program verified and stored relevant demographic data (age, sex, region of residence and patient enrollment category), and a randomly generated unique number was assigned to each serum tested for antibody to HIV. All personal identifiers were destroyed before testing.

Based on information obtained from specimen requisition, patient sera were divided into five categories: infants (serodiagnostic testing of sick babies), injection drug users, pregnant women (all are routinely tested for syphilis), persons with STD or their contacts, or persons tested for routine reasons such as visa, admission to hospitals, etc. The STD category included persons with STD symptoms as well as persons (age 15 to 30 years) seen in clinics identified as caring for a 'high risk' STD clientele. Age, sex and regional data for the composition of Manitoba's population were obtained from Manitoba Health Services Commission.

From April 1, 1990 to September 30, 1991, 50,929 persons were entered into the study, and their sera were tested for antibody to HIV (3). A total of 2789 persons tested during the first year were retested during the last six months of the study (2207 of these were women). The total number of persons enrolled in the study by age group, sex, region of residence and patient category were entered in a personal computer database, along with data on Manitoba's population. A tabulation by sex, age, region and patient category, maintained at Cadham Provincial Laboratory for all positive specimens, was merged with the database to permit calculation of rates of positivity and testing. Statistical analysis software was used in the statistical analysis. Rates were calculated per 10,000 population (or 10,000 persons tested). The 95\% confidence intervals for rates of positivity were calculated using the Poisson distribution. In instances where less than 100 samples were tested, conference intervals were not reported. 


\section{RESULTS}

The number of males and females tested during each month of the 18-month study for the main enrollment categories is presented in Figure 1. The number of persons tested each month remained relatively constant throughout the study and only a small fraction of these were in the STD category.

Table 1 provides an overall study summary, and indicates the number of sera tested and the results obtained in each patient category. One hundred and thirty-three persons were found to have antibodies to HIV $(0.26 \%)$. The number of HIV-positive males and females by enrollment category for each of the study's 18 months is illustrated in Figure 2, which clearly shows that almost all the positives were in the STD category and that more positives were detected in 1991 than in the corresponding nine-month period in 1990. Females represented $77.7 \%$ of the persons tested, but only $7.5 \%$ of the positives, with an overall HIV prevalence of $0.025 \%$. Only two of the 27.627 pregnant women tested had HIV antibodies, for a rate of 0.72 per 10,000 (confidence interval: 0.1 to 2.6 ).

In the routine test and STD categories, an almost equal number of males and females were tested. There were significantly more positive males than females in both these categories $(\mathrm{P}=0.003$ and $\mathrm{P}<0.001$, respectively). Overall, 123 of the 11,314 males tested (1.08\%) had HIV antibodies and 111 of the 123 positive males $(90.2 \%)$ were in the STD category.

The total number of persons tested was almost identical in each of the three consecutive six-month periods studied, yet a significant increase in the number of positives was noticed in the second six-month period when compared with the first six months $(\mathrm{P}<0.001)$ (Figure 3). Since no positives were detected in the 137 infants and 83 injection drug users tested, these categories are not shown in Figure 3.

An analysis of the age group, sex, region of residence and enrollment category of the 54 positives detected from April 1 to September 30, 1991, suggests that a maximum of 13 persons may have tested positive during the preceding 12 -month period. The study design ensured that the 79 persons found positive during the first 12 months of the study had been tested only once during that period. Similarly, individuals in the last six months of the study were tested only once.

Approximately 56\% of Manitoba's population of $1,130,845$ reside in Winnipeg; of the 133 positives, 111 (83.4\%) reside in Winnipeg. While the rate of testing decreases with age for Winnipeg males in the STD category, the rate of HIV positivity increases for each decade of age (from 15 to 44) (Figure 4). A similar pattern (data not shown) was noticed in the 16 HIVpositive males in the STD category who resided outside of Winnipeg. This observation may perhaps be explained by the long incubation period of the HIV virus and the fact that antibodies usually remain detectable
TABLE 1

Manitoba unlinked human immunodeficiency seroprevalence study: April 1, 1990 to September 30, 1991

\begin{tabular}{|c|c|c|}
\hline Category & $\begin{array}{l}\text { Number positive/ } \\
\text { number tested }\end{array}$ & $\begin{array}{c}\text { Rate } / 10,000 \text { tested } \\
(95 \% \mathrm{Cl})\end{array}$ \\
\hline \multicolumn{3}{|l|}{ Infants } \\
\hline Female & $0 / 69$ & - \\
\hline Male & $0 / 68$ & - \\
\hline \multicolumn{3}{|l|}{ IDUs } \\
\hline Female & $0 / 31$ & - \\
\hline Male & $0 / 52$ & - \\
\hline \multicolumn{3}{|l|}{ Prenatals } \\
\hline Female & $2 / 27,627$ & $0.72(0.1$ to 2.6$)$ \\
\hline \multicolumn{3}{|l|}{ Routine } \\
\hline Female & $2 / 3959$ & $5.1(0.5$ to 18.2$)$ \\
\hline Male & $12 / 3437$ & $34.9(18.0$ to 61.1$)$ \\
\hline \multicolumn{3}{|l|}{ STD } \\
\hline Female & $6 / 7929$ & $7.6(2.8$ to 16.5$)$ \\
\hline Male & $111 / 7757$ & $143.0(116.5$ to 169.7$)$ \\
\hline \multicolumn{3}{|l|}{ Total } \\
\hline Female & $10 / 39,617(0.025 \%)$ & - \\
\hline Male & $123 / 11.314(1.08 \%)$ & - \\
\hline All & $133 / 50,929(0.025 \%)$ & - \\
\hline
\end{tabular}

Cl Confidence interval; IDU Injection drug user; STD Sexually transmitted diseases

for life, possibly signifying that the HIV infections detected were old HIV infections.

\section{DISCUSSION}

This is the first report in Canada from a public health laboratory of an unlinked HIV seroprevalence study in persons investigated for an STD using blood drawn for syphilis serology. Manitoba's health guidelines recommend testing for syphilis for all pregnant women and all

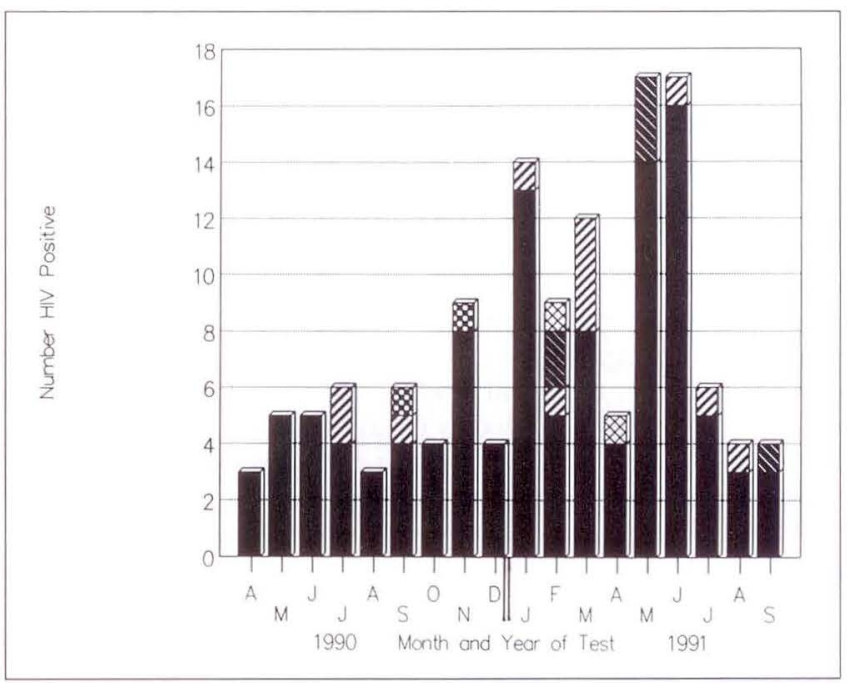

Figure 2) The number of males and females found positive for human immunodeficiency virus (HIV) antibodies for each enrollment category in which positives were detected and for each of the 18 months of study. Male sexually transmitted diseases: Male routine; Female sexually transmitted diseases: Female routine 


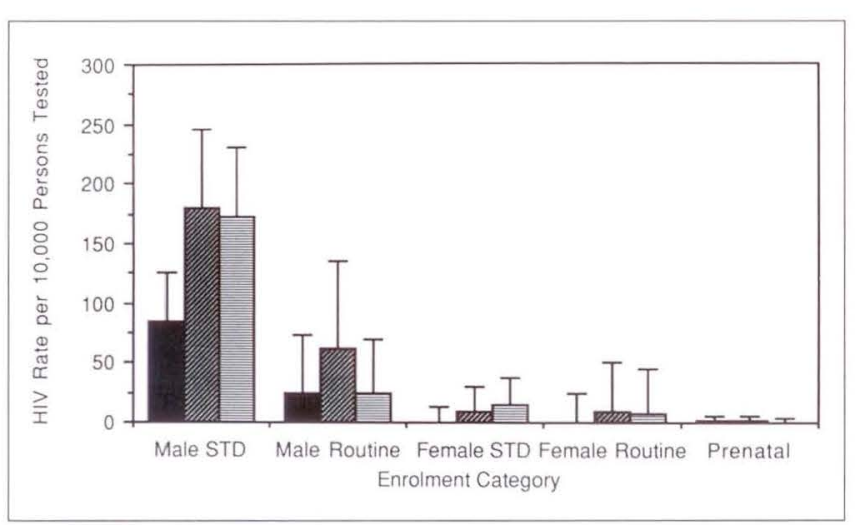

Figure 3) Rate of human immunodeficiency virus (HIV) positivity for males and females for each enrollment category for each of the study's six-month periods. April 1, 1990 to September 30, 1991: October 1. 1990 to March 31, 1991: April 1. 1991 to September 30, 1991: T Upper limit of 95\% confidence

patients with STD. In Manitoba, almost all pregnant women and all women scheduled for abortion are tested for syphilis, but the compliance for such testing for STD patients is unknown. A questionnaire sent to Manitoba physicians after the completion of this seroprevalence study indicated that only $50 \%$ of responding practitioners comply with the syphilis testing guidelines (6). All laboratory-based surveys, such as this study, have other inherent limitations because laboratories have little control over the information accompanying the specimens to be tested. particularly with regard to the exact clinical data.

Despite these limitations, Manitoba's unlinked seroprevalence study has shown that the overall HIV positivity is low in Manitoba $(0.26 \%)$. The prevalence of HIV in pregnant women is much lower than the 2.7 per 10,000 pregnant women reported in British Columbia (4) or the 6.1 per 10.000 live births in Quebec (5). This study suggests that strategies for the control of HIV should be focused on males and on persons with a history of STD, particularly those residing in large

ACKNOWLEDGEMENTS: The authors thank Deanne Wasylyshen, Andrea Hovey, Debbie Chochinov, Dawna Carmichael and Celso Macaset who worked on this study. Peggy Bond who typed the manuscript, Susan Van Cuylenburg who provided the computer programming and Dr M O'Shaughnessy of the Federal Centre for AIDS who confirmed the indeterminate sera. This study was funded by Grant Number 66071549 AIDS from the National Health Research and Development Program which we acknowledge with thanks.

\section{REFERENCES}

1. AIDS - A perspective for Canadians, summary report and recommendations. Royal Society of Canada. 1988.

2. Federal Centre for Acquired Immune Deficiency Syndrome Working Group on Anonymous, Unlinked HIV Seroprevalence. Guidelines on ethical and legal considerations in anonymous, unlinked HIV

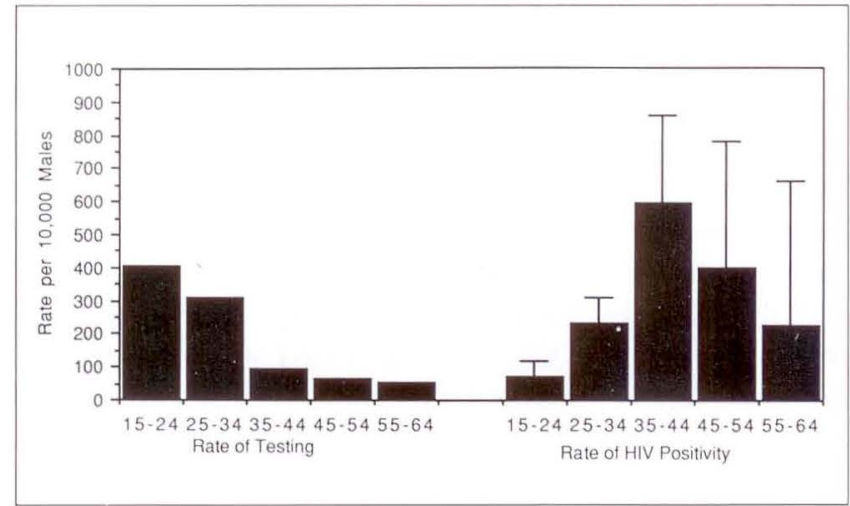

Figure 4) Rate of testing contrasts with the rate of human immunodeficiency virus (HIV) positivity for five 10-year age groups of males in sexually transmitted diseases category residing in Winnipeg. T Upper limit of $95 \%$ confidence

urban centres. Of the 111 positive males in the STD category, 95 (85.5\%) resided in Winnipeg. A number of these HIV-positive males may have been identified by Manitoba's serodiagnostic program. The design of the serosurvey does not allow any personal identification, so the number of new seropositives could not be determined. In the STD category, more males were tested in Winnipeg than outside of Winnipeg, and there were more positive in (versus outside of) Winnipeg; $1.68 \%$ positivity in Winnipeg (54 positives out of 3203 tested) and $0.58 \%$ outside of Winnipeg (11 positives out of 1877 tested). It is important to note that clinics attended by high risk clientele are mainly located in Winnipeg. Clinicians should think of HIV in any patient with a past or present history of STD.

\section{RECOMMENDATION}

Results suggest an urgent need to target strategies for the control of HIV in persons with STD, particularly males in large urban centres. HIV-1 case finding should be routine for STD patients.

seroprevalence research. Can Med Assoc J 1990:143:625-7.

3. Sekla L, Hammond G, Stackiw W, Eibisch G, Tate R. Manitoba HIV seroprevalence study. Can Dis Weekly Rep 1991:17-33:179-84.

4. Schechter M, Ballen P, Buskard N, et al. An anonymous seroprevalence survey for HIV infection among pregnant women in British Columbia and the Yukon Territory. Can Med Assoc J 1990: 143:1187-92.

5. Hankins C, Laberge C, Lapointe N, Lai Tung MT. Racine L, O'Shaughnessy M. HIV infections among Buebec women giving birth to live infants. Can Med Assoc $\mathrm{J}$ 1990:143:885-93.

6. Hammond G. Shewchook S, Tate R. Sekla L. Physicians' attitudes and practice of HIV testing. Presented at The Canadian Association for HIV Research Second Annual Canadian National Conference on HIV/AIDS. Vancouver, BC, May 28-29, 1992. 


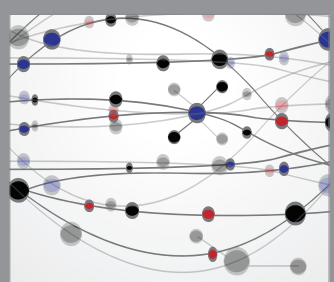

The Scientific World Journal
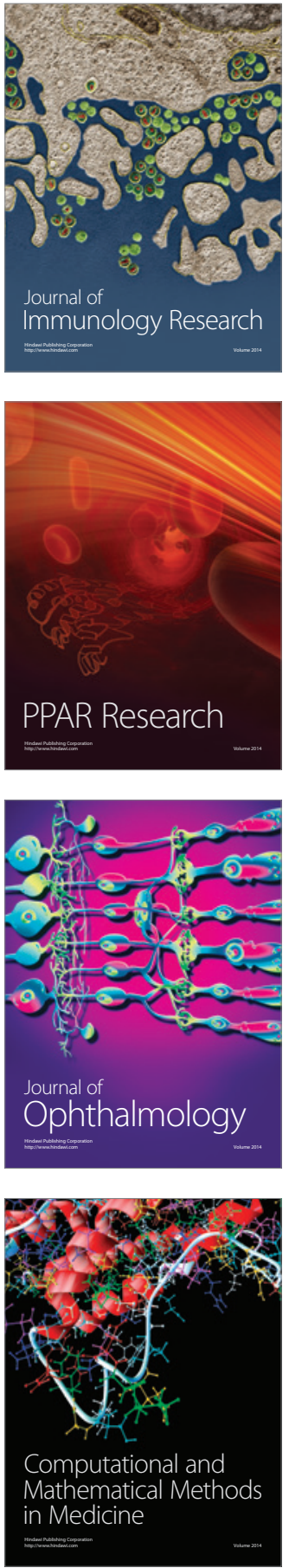

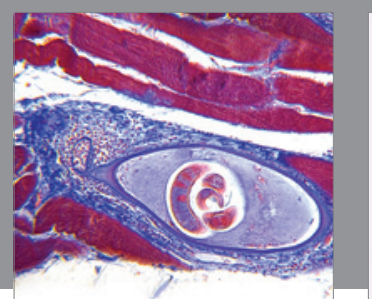

Gastroenterology Research and Practice

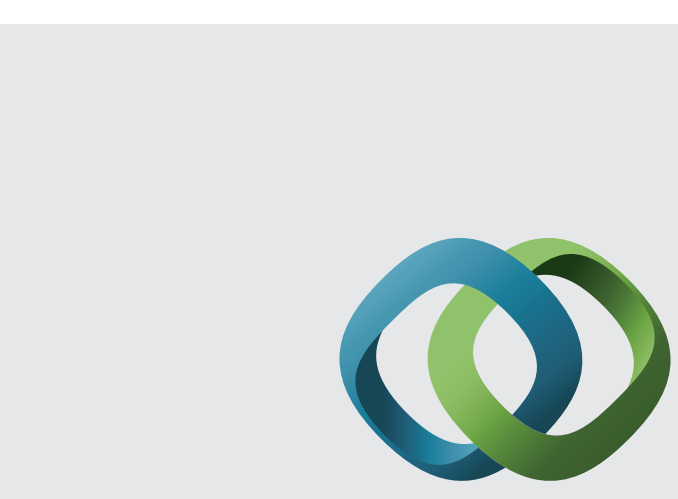

\section{Hindawi}

Submit your manuscripts at

http://www.hindawi.com
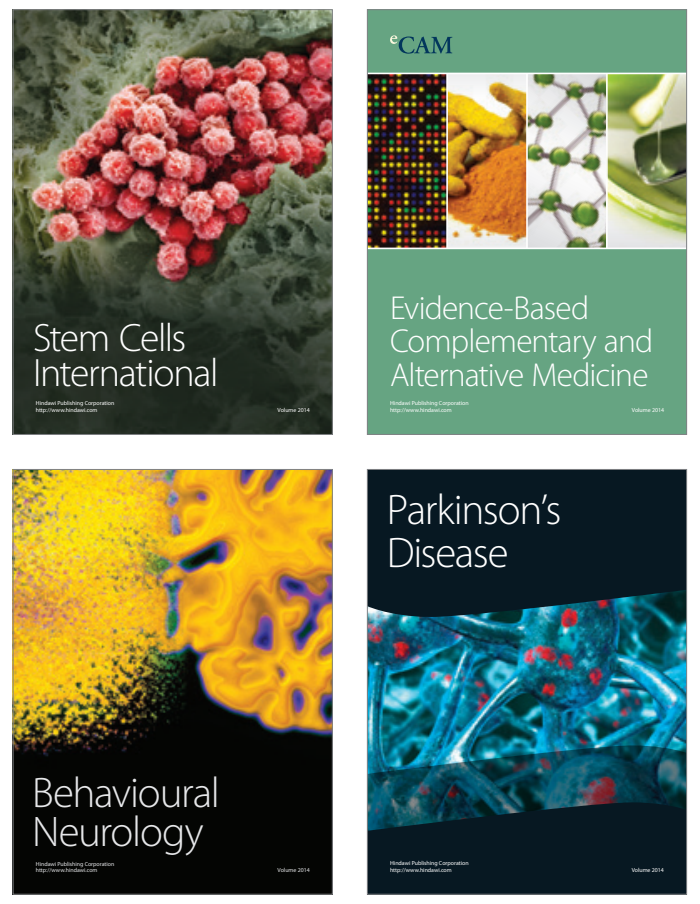
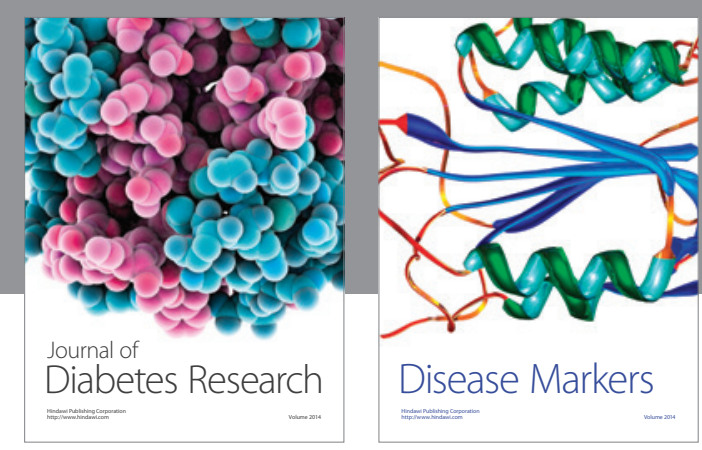

Disease Markers
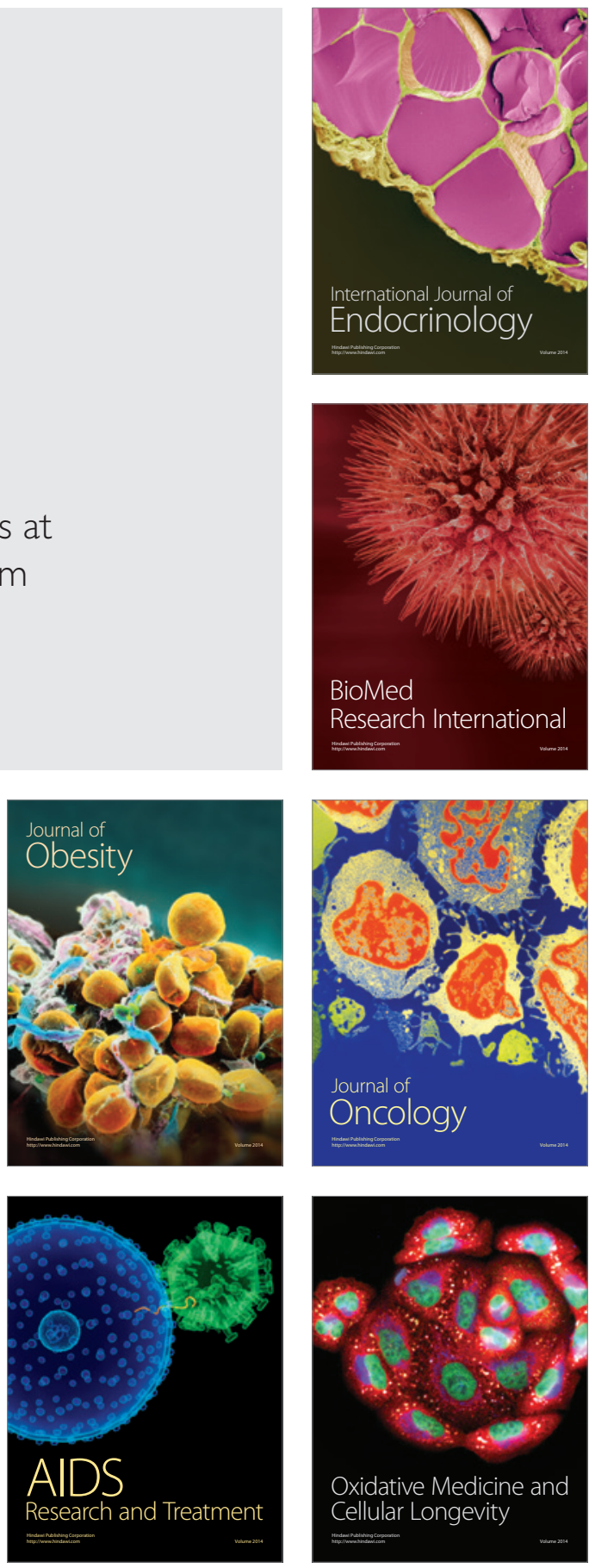